\title{
Mariella Di Maio, «La plus horrible de toutes les scènes»: la Bérésina de Balzac
}

\section{Marco Stupazzoni}

\section{(2) OpenEdition}

1 Journals

\section{Edizione digitale}

URL: https://journals.openedition.org/studifrancesi/39591

DOI: 10.4000/studifrancesi.39591

ISSN: 2421-5856

\section{Editore}

Rosenberg \& Sellier

\section{Edizione cartacea}

Data di pubblicazione: 1 décembre 2004

Paginazione: 390

ISSN: 0039-2944

\section{Notizia bibliografica digitale}

Marco Stupazzoni, «Mariella Di Maio, «La plus horrible de toutes les scènes»: la Bérésina de Balzac», Studi Francesi [Online], 143 (XLVIII | II) | 2004, online dal 30 novembre 2015, consultato il 19 mai 2021. URL: http://journals.openedition.org/studifrancesi/39591; DOI: https://doi.org/10.4000/studifrancesi. 39591

Questo documento è stato generato automaticamente il 19 mai 2021.

\section{(c) (1)}

Studi Francesi è distribuita con Licenza Creative Commons Attribuzione - Non commerciale - Non opere derivate 4.0 Internazionale. 


\title{
Mariella Di Maio, «La plus horrible de toutes les scènes»: la Bérésina de Balzac
}

\author{
Marco Stupazzoni
}

\section{NOTIZIA}

MARIELLA DI MAIO, «La plus horrible de toutes les scènes»: la Bérésina de Balzac, in Napoléon, Stendhal et les romantiques. L'Armée - la guerre - la gloire. Actes du Colloque organisé par le Musée de l'Armée, Stendhal aujourd'hui (Société Internationale d'Études Stendhaliennes) et $H B$ (Revue internationale d'études stendhaliennes). Paris - Musée de l'Armée, 16-17 novembre 2001. Textes réunis par Michel ARROUS, Saint-Pierre-du-Mont, Eurédit, 2002, pp. 221-236.

1 Pubblicato in prima edizione ne «La Mode» di Émile Girardin tra il 15 maggio e il 5 giugno 1830, Adieu ha trovato la sua collocazione definitiva soltanto nel 1835 all'interno delle Études philosophiques. Racconto "filosofico", dunque, dai marcati contorni storici che rendono lo scritto balzachiano ancor più suggestivo se considerato alla luce del mito napoleonico così ampiamente presente nell'immaginario creativo dello scrittore. Adieu è fondamentalmente il racconto di una tragedia, di un dramma storico (la disfatta francese della Beresina) che penetra prepotentemente nei risvolti più intimi e profondi della storia e della psicologia dei personaggi. In questo senso, osserva bene l'A., per Balzac, «le drame de la retraite de Russie représente une expérience extrême, une expérience des limites, qui marque une régression infinie» (p. 225). Dal punto di vista della struttura e delle dinamiche narrative proprie dell'opera, Balzac si avvale di uno schema narrativo, quello della ripetizione, attraverso cui la compenetrazione tra modello storico e registro teatrale risulta particolarmente efficace. In Adieu, scrive l'A., «un thème joue un rôle essentiel: celui de la reproduction du monde, de la compétition entre Histoire et théâtre. Ce thème est traité sur le registre catastrophique et apocalyptique» (p. 231). La disfatta della Grande Armée in terra di Russia rappresenta, a tutti gli effetti, la fine di un mondo: in piena Restaurazione, Philippe de Sucy (il protagonista del racconto insieme a Stéphanie de Vandières), vecchio soldato di 
Napoleone, «essaie de réconstituer une page d'histoire, un épisode du passé» configurandosi, allo stesso tempo, come storico e regista del dramma. Attraverso questa ricostruzione, egli spera, invano, di «donner un avenir à la femme qu'il aime», di ridarle «la raison et la plonger à nouveau dans la dimension du temps et de l'espace, qui est le propre de l'Histoire» (p. 232). 